\title{
LEGAL STUDY ON THE FOUNDATION OF THE FLAT OWNERS AND RESIDENTS ASSOCIATION(PPPSRS)
}

\author{
R. Suharto, Yudhi Hendra Kristian \\ Faculty of Law, Diponegoro University \\ r.suhartoo@gmail.com
}

\begin{abstract}
Practically, many developers did not facilitate the foundation of the flat owners and residents association (PPPSRS) as what has been regulated in Law No.20/2011 on Flats. Many owners or residents of flats do not really care on the responsibility of creating PPPRS based on article 74 number 1. The researcher wanted to know the lawful effects to the developer after the absence of PPPSRS and the lawful follow up should be done in the end.
\end{abstract}

Keywords: Flats Owner and Residents Association, Torts.

\section{Introduction}

In the development of housing and residences, the availability of land is an important thing. The availability of land is important to build certain houses and flats. There will not be any problems in building the construction of house based on the demands of the developer, whether it will be constructed horizontally or vertically. Along with the population growth and the necessity of housing in a widening scale, the availability of land is relatively decreasing instead. Thus, a vertical housing model is made in the form of flats to minimize the use of land. ${ }^{1}$

Flats is a vertical building structured functionally horizontal and vertical with a clear border in each unit, clear size, and width, and owned separately. A unit of a flat can be owned by an individual who is owned by the owner and communal related to the necessity of many. The use and management of flats should be controlled by certain association with authority and responsibility. There are several laws regulating the association of owners, including Law No.16/1985 about Flats, Ministry Law No. 4/1988 and Ministry’s Provision on Civil Housing Number: 06/KPTS/BKP4N/1995 about the Guidance of Creating Deed of Incorporation, Articles

\footnotetext{
${ }^{1}$ Muhammad Yasin Lubis, Abdul Rahman Lubis, Kepemilikan Property di Indonesia, Termasuk Kepemilikan Rumah Oleh Orang Asing, (Bandung: Mandar Maju, 2013), page 53.
} 
of Association and Bylaws of Flats Owners Association, and Law No.20/2011 on Flats (Flats Act).

Owners Association in Law No. 16/1985 called as Flats Owners Association, and Law No.20/2011 called as Flats Owners and Residences Association of "PPPSRS." These bodies are functioned and roled importantly in directing to the management policy of communal things, parts, and lands. So, it is important for the owners, residences, and controllers of flats to create PPPSRS.

Actually, there are several developers who irresponsibly do not facilitate the creation of PPPSRS as what has been made by the Law, somehow, they are still controlling the management of the flats, management body, taking the advantages of the third party and controlling the communal things, and taking benefits of the communal lands and parts for themselves, without paying the required money with the existence of PPPSRS, like in article 74 number (1) along with administrative sanction mentioned in Article 107 jo. Article 108 Law No.20/2011 on Flats. The execution of developers in facilitating the creation of PPPSRS is the key of mandate sharing from Commercial Flats Ownership to the Organization of Flats Owners like Chapter VII about The Management, Chapter III about Quality Improvements, Bab X about Second Part Institution about PPPSRS, but, there are some developers who do not facilitate the creation of PPPSRS or do not allow the creation of PPPSRS because of economical motives.

Ibnu Taji, The Head of Flats Residences Association (Apersisi) states, ${ }^{2}$ "Conflicts always happen between the owner and residences of apartment and to the managing party chosen by the Association of Flats Owners and Residences (PPPSRS). Since the PPPSRS only reflects the necessity of the owners where they control the tuition without any transparency. Therefore, the consumers can do nothing for it."

The article 1(1) of Flats Act defines flat as a multi-level buildings constructed in an environment divided into sections of horizontal and vertical functional structures, and are units that each can be owned and used separately, especially for shelter equipped with shared segments, goods, and grounds. In its Elucidation, Flats, as designated in the Law, shall be a term that provides a legal sense which is multi-level buildings that always contain a system of

\footnotetext{
${ }^{2}$ Apersisi: Tunda Beli Apartemen untuk Hunian, diakses pada: www.katada.co.id/, tanggal 21 Februari 2015. 260 
individual ownership and collective rights for residential use or non-residential, either independently or in an integrated manner as a single system of development.

It can be concluded in the Law No. 20/2011 that not every multi-level buildings could be considered as flat to the extent that the building satisfied the characteristic of flat. Therefore, the flat is indeed a multi-level building, but not every multi-level buildings can be called as flat. There are a lot of terms for multi-level buildings category used for housing such as apartment and condominium.

The apartment was often used by developers to marketized their flats. The Indonesian Official Dictionary defines apartment as a residence contains living room, bedroom, bathroom, kitchen and others in a single floor of a multi-level building, which also has various facilities such as pool, gym, grocery, etc. ${ }^{3}$

The object of flat unit ownership besides individual ownership units is also includes shared segment, goods, and grounds. Therefore, whether it is individual or collective ownership, it still considered as one entity. However, the term of condominium, according to the Indonesian Official Dictionary, is collective ownership (in sociological aspect); as a regional which managed together (in political aspect); and as a major, luxurious, multi-level buildings which rented or equated to the definition of apartment. ${ }^{4}$ According to Legal Analysis and Evaluation Team on Legal Standing of Ownership Certificate of Flat Units, condominium could be defined as a sectioned ownership system of a building; each is a segmented unit which can be owned individually and other parts of the condominium also available to be owned collectively. ${ }^{5}$ The term of condominium is, etymologically, based on two words, "co" from collective and "dominium" means ownership. Therefore, condominium is a kind of collective ownership.

Flat units can be owned individually or by other legal entity such as corporate to the extent that the legal subject has fulfilled the requirement of being an owner. The ownership of strata title of flat units only applied to the single unit and not including other parts in the flat in the sense of territorial aspect. ${ }^{6}$ The characteristic of the ownership, individual or collective, demands a foundation of the resident union. As for flat units is a single ownership, and collective rights

\footnotetext{
${ }^{3}$ Departemen Pendidikan Nasional, Kamus Besar Bahasa Indonesia ed. 4, (Jakarta: Gramedia, 2008), hal. 80

4 Ibid, hal. 722

${ }^{5}$ Badan Pembinaan Hukum Nasional, Departemen Kehakiman, op. Cit, hal. 14

${ }^{6}$ Adman Sutedi, Hukum Rumah Susun dan Apartemen, (Jakarta: Sinar Grafika, 2012), hal. 146
} 
concerned people's interest, therefore, the resident union have authority to manage collective interest.

\section{Research Method}

In writing this law article, the researcher used normative juridical approach. Juridical is related to the way of analyzing related lawful principles and bases to this research, while the "normative" is lawful research based on the literature review or secondary data research coping the lawful bases, rules, and convention. So, the normative juridical approach uses the research approach based on Law problems in which one law is related to another law and its application.

In the data source of this article writing, the researcher used secondary data, consist of primary law materials, secondary law materials, and tertiary law materials, such as:

1) Primary Law Materials is a bonding lawful material, such as Criminal Codes, Law Number 20 Year 2011 about Flats, PP No. 4 Year 1988 about Flats, The Ministry’s Provision of Society’s Changing Number: 06/KPTS/BKP4N/1995 about The Guidance of Deed of Incorporation, Articles of Association and Bylaws related to Flats Owners Association, and The Ministry Provision on People's Housing Number: 11/KPTS/1994 about The Guidance of Association of Flats Unit Trading.

2) Secondary Law Material is the law which is related to primary law and can help in analyzing and understanding the primary law, such as civil law book, scientific papers, and any other things related to flats.

3) Tertiary Law Materials is the material giving information about primary and secondary law materials, from Kamus Besar Bahasa Indonesia (KBBI)/ Indonesian Dictionary.

\section{Findings and Discussions}

\subsection{Lawful Effects to Commercial Flats Owners who Do Not Facilitate the Creation of Flats Unit Owners and Residences Association}

Public flats with individual ownership can be managed by the owner or collectives which can be used and managed together since it has the necessity of many residences. The

\section{2}

Diponegoro Law Review, October 2017, Volume 02, Number 02 
use and management of flats and its environment should be managed and done by the Association of Flats Owner and Residences.

The importance Flats Owners and Residences Association (PPPSRS) in Commercial Flats Owners are PPPSRS have several tasks and responsibilities to manage and control the environment around the flats and regulating the rules of the residences, and also creating and choosing the managers based on the Articles of Association and bylaws of PPPSRS. Under the provision of Governmental Law Number 4 Year 1988 about Flats, Article 56 states that the function of residences and owners association are:

1) Building healthy, orderly, and secure environment;

2) Managing and Building the Necessity of Owners; and

3) Managing Flats and its environment.

The main tasks of Association of Owners are listed in Article 59, they are:

1) Ratifying the Articles of Association which is arranged by the controllers of meeting in Owners Association;

2) Managing the owners to the direction of harmonious, in tune, and balanced in Flats and environments;

3) Controlling the execution of provisions based on Articles of Association and Bylaws;

4) Organizing the Administrative Tasks;

5) Choosing or Creating and Controlling the controller body in managing flats environment;

6) Organizing the bookkeeping and money administration separately as the Owner Association wealth;

7) Setting the sanction of violation of articles of association and bylaws.

Based on the function and task, the existence of PPPSRS inside of Commercial Flats Owners is an absolute thing needed as mandated in law whether in Law No. 16 Year 1985 about Flats and the execution of Law No. 20 Year 2011 about Flats. Nevertheless, the execution of this law has never been done before. So, execution of the law should be based on governmental Law Number 4 Year 1988 about Flats and Ministry's Provision on People's Housing Nomor 11 Year 1994 about Flats Trading Association Guidance, and Ministry’s Provision of People's Housing Number: 06/KPTS/BKP4N/1995 about The Guidance of 
Deed of Incorporation on Articles of Association and Bylaws of Flats Residences Association.

In the statutory provisions of Law number 20 of 2011 on Flats, article 75 paragraph 5 (1), the residents association must facilitate the creation of PPPSRS at least before the end of transition submission flat units from the residents association to the flat owner. In article 59 paragraph (2), the transition period itself cannot be more than 1 (one) year since the first flat submission to the flat owner. After PPPSRS is created, the resident association hands over the management of common areas, amenities, and facilities to the PPPSRS. This obligation cannot be found in Law number 16 of 1985, but almost the same obligation is stated in Government Regulation number 4 of 1988 about Flats, article 57 paragraph (4) which says: "The developers must act as the administrator of the temporary association before the true association of residents is created, and help the preparation of the creation of the true resident association as soon as possible." In both of those regulations, the responsibility imposed on the developers is not accompanied by the covenants if the responsibility is not performed or fulfilled.

According to the provisions of article 37 paragraph 1 of Government Regulation number 24 of 1997 on Land Registration Act, it emphasizes that the transition of the land rights and ownerships of the flats is through sell and purchase, trade, bequest, company data input, and other legal acts of right transition, except the assignment though an auction that can only be registered with the proven deed made by Land Deed Official Certifier (PPAT) which has the authority based on the applied regulations. The Lease Agreement/Deed of Sell and Purchase made by PPAT is intended to give legal certainty to the land rightful holder (the purchaser).

The act of flat transition is not deliberately done from the developers to the purchasers, but it needs times because there are many units of flats/apartments which have been built or there are still some flats which are not sold, so there is still 1 (one) year the transition process left to give legal certainty to the purchasers. Even though the first flat transition the commercial property has not yet handed the flat ownership from the developers to the purchasers because the agreement is still in the form of Sale and Purchase Agreement (PPJB) and it is not in the form of Lease Agreement (AJB) followed the process of title deed transfer 
in the freehold (SHM Sarusun). In the provision of article 1 Law number 20 of 2011 on Flats Act, it is mentioned that freehold therein after regarded as SHM Sarusun is the proof of flat ownership there-over freehold, rights to build, or rights to use state-owned lands, also right to manage. In reality, although the multi-story building units are occupied by either the purchaser or the tenant, this does not make the developers want to facilitate the creation of PPPSRS. If the Right of Strata Title Ownership on Multi-storey Building Units with the name of the rightful owner is out, but the developers do not facilitate the creation of PPPSRS, then it can be said that the developers commit an act against the Law which is an act against the legal responsibility from the doer.

Torts was regulated in article 1365 until 1380 of Indonesian Civil Code. Article 1365 asserts that every illegitimate act which could bring loss to another person, so that the person caused such losses, must pay. The clause of "illegitimate," according to MA Moegni Djojodirdjo, only reflect the active trait of the torts, yet the passive trait was not, as the term defined such definition of torts as an active act. ${ }^{7}$

If a person deliberately caused damage or loss to others, then the active trait of the "illegitimate" clause appeared. Otherwise, the meaning of passive trait in torts would appear if a person deliberately did not act or merely leave in something happened even though its contrary to his obligation to do such act to prevent somebody losses. Therefore, the aspect of "against the law" could be applied. This passive trait was designated in Indonesian Civil Code article 1565 , asserts that "every person obliges not only to the loss due to his/her deeds but also to his/her omission to act or imprudence." Those two articles underline that torts law not merely encompass the deed but also negligence. According to article 1365, torts must satisfy these elements, such as :

1) There are deeds that were done

2) The deed violated the law

3) The deed violated other person rights that lawfully guaranteed

4) The deed was contrary to the doer's lawful obligation

5) The deed was contrary to the doer's ethical obligation

6) The deed was contradicted to social interest

${ }^{7}$ MA. Moegni Djojodirdjo, Perbuatan Melawan Hukum, (Jakarta: Pradnya Paramita, 1982) hal. 13 
7) There is a loss due to the deed

In Legism school of thought (19th century), torts defined as an act or an omission to act that illegitimate against the doer's obligation or violating other person rights. Therefore, legalism thought defined a core element of the tort, which its illegitimately violating other person rights. ${ }^{8}$ Legism emphasized that not every act caused such losses that could be charged for indemnity. Otherwise, only an illegitimate act that could be accounted for charging such indemnity.

Legalism also had been challenged by other scholars such as Molengraaf, who asserts that torts were not only fixated on the illegality of the act, but the act also must be violated the norms. However, in 1919, the decision of the Hoge Raad or Netherland Supreme Court brought a broad interpretation of torts. The decision asserts that the legal formulation within Heemskerk or torts is an act or omission to act which either violates another right or is contrary to one's obligation under law or an act contrary to either morality or to prudence to be observed in the community towards a person or his property. The decision was issued in "Standard Arrest" on January 31st, 1919 in Cohen v. Lindenbaum case. ${ }^{9}$

Due to this broad interpretation of article 1366, the article is no longer considered important. The first part of the decision refers to a violation of subjective rights which generally are rights granted by statute to someone (rights in rem of the owner of the property, tangible or intangible, rights of a secured party). Most commentators do not include contractual rights in the category of subjective rights as the violation of contractual rights are specifically regulated in article 1243 of the Indonesian Civil Code.

3.2. Legal Efforts that can be done by the Owners and the Residents of the Multi-storey Building Units If the Developers of the Multi-storey Building Unit Freeholds do not fulfill their responsibility in facilitating the creation of Flats Owner and Residents Association

In the Laws number 20 of 2011 on Flat Act, the developers are responsible for facilitating the creation of Flats Owner and Residents Association. However, when the developers do not fulfill

${ }^{8}$ Rahmat Setiawan, Tinjauan Elementer Perbuatan Melawan Hukum (Bandung: Alumni, 1982). Hal. 15

${ }^{9}$ Rahmat Setiawan, op. cit

266

Diponegoro Law Review, October 2017, Volume 02, Number 02 
their responsibility, in the accordance to the regulation thereabouts or the developers do something against their legal responsibility, then it can be said that they commit an act against Laws or a tort.

A trot in the form of unfulfilled responsibility of facilitating the creation of PPPSRS will result in the failure of creating PPPSRS, so the developers keep dominating the management of common areas, amenities, and facilities and also the expendiency of financial advantage for the developers and conversely, it causes financial damages to the owners and residents. The efforts that can be done by the owners and residents of the flats appears if the developers do not fulfill their responsibility to facilitate the creation of PPPSRS through asking for a discussion with the developers, so that they will call all owners and/or all residents of the flats with the agenda of creating Flats Owner and Residents Association for the first time, including providing the adequate room and equipment in the flat/apartment surroundings.

If the discussion cannot be conducted or can be conducted, but it cannot reach an agreement, then the owners and/or the residents of flats can submit a suit through District Court of Justice in the place where the flats are with the intention of forcing the developers to fulfill their legal responsibility to facilitate PPPSRS creation, or undergo the damage claims regarding the damages arose because of the developer who continuously dominate and control the management of common areas, amenities, and facilities which should be shift to PPPSRS if PPPSRS is created. Thereon it also asked the District Court of Justice to make the developers release their control on the freehold of the flats, except the flats which have not been sold, so the developers have the same position as the owners and the same rights and obligations as the owners and the residents.

\section{Conclusion}

Based on the findings and discussion, it can be concluded that the regulation of Law Number 20 Year 2011 about Flats, specifically regarding public Flats and Commercial Flats/ Apartments. In details, Article 75 demands the developer of Flats to facilitate the creation of Owners and Residences of Flats Association (PPPSRS) and this responsibility should be done a year before the ending of the transition period. The limit of transition period can be done not more than one year after the flats unit for the first time to the owner of flats unit. The limit of the 
transition period is aimed to guarantee the lawful assurance and ownership rights in controlling the management of flats unit. The developer of flats unit on commercial ownership rights/ apartments which is not doing the responsibility of facilitating the PPPSRS, so, the developers can be categorized as aginst the law as regulated in Book of Civil Law in Indonesia.

Under the provision of Article 75 (number 1) in Law No. 20 Year 2011 about Public Flats, or Governmental Law No. 4 Year 1988 about Public Flats, so, the responsibility of the developers to facilitate the creation of PPPSRS is not completed with the firm sanctions. Nevertheless, the responsibility of the public flats developer to create PPPSRS, so, the owners and residences of Flats can file a lawsuit in where the flats exist based on the condition of against the law.

\section{References}

\section{Books}

Adiwinata, Saleh, Pengertian Hukum Adat Menurut Undang-undang Pokok Agraria, Bandung: Alumni, 1980.

Badan Pembinaan Hukum Nasional Departemen Kehakiman, Analisa and Evaluasi Hukum about Kedudukan Hukum and Sertipikat Kepemilikan Flats, Jakarta, 1994.

Departemen Pendidikan Nasional, Kamus Besar Bahasa Indonesia, Pusat Bahasa, edisi ke-4, Jakarta: PT. Gramedia Pustaka Utama, 2008.

Djojodirjo, Ma. Moegni, Perbuatan Melawan Hukum, Jakarta: Pradnya Paramita, 2008.

Fuady, Munir, Hukum Kontrak (dari sudut pandang hukum bisnis), Bandung: Citra Aditya Bakti, 1999.

Fuady, Munir, Perbuatan Melawan Hukum Pendekatan Kontemporer, Bandung: Citra Aditya Bakti, 2013.

Halim, A. Ridwan, Sendi-sendi Hukum Hak Milik Kondominium, Flats and Sari-sari Hukum Benda (Bagian Hukum Perdata), Jakarta: Puncak Karma, 1990.

Hamzah, Andi, Dasar-dasar Hukum Perumahan, Jakarta: Rineka Cipta, 2006.

Hutagalung, Arie Sukanti, Kondominium and Permasalahannya, Edisi Revisi, Depok: Badan Penerbit Fakultas Hukum Universitas Indonesia, 2002. 
Kuswahyono, Imam and Akis, Mimi Rosidi, Konsepsi Hak Milik atas Satuan Flats dalam Hukum Agraria, Malang: Setara Press, 2010.

Lubis, Muhammad Yamin and Lubis, Abdul Rahim, Kepemilkan Properti di Indonesia, Termasuk Kepemilikan oleh Orang Asing, Bandung: Mandar Maju, 2013.

Setiawan, Empat Kriteria Perbuatan Melawan Hukum and Perkembangan Dalam Yurisprudensi, Varia Peradilan No. 16 Year II, 1987.

Setiawan, Rachmat, Tinjauan Elementer Perbuatan Melawan Hukum, Bandung: Alumni, 1982.

Soemitro, Ronny Hanitijo, Metode Penelitian Hukum and Jurimetri, Jakarta: Ghalia Indonesia, 2002.

Soekanto, Soerjono, Pengantar Penelitian Hukum, Jakarta: Universitas Indonesia Press, 1984.

Subagyo, P. Joko, Metode Penelitian Dalam Teori and Praktek, Jakarta: Rhineka Cipta, 1991.

Sunggono, Bambang, Metodologi Penelitian Hukum, Jakarta: PT. Raja Grafindo Persada, 1998.

Sutedi, Andrian, Hukum Flats and Apartemen, Jakarta: Sinar Grafika, 2012.

Syahrani, Ridwan, Seluk Beluk and Asas-asas Hukum Perdata, Bandung: Alumni, 2006.

\section{Laws}

Book of Civil Law

Laws about Flats. UU No. 16 Year 1985, LN No. 75 Year 1985. TLN No. 2043

Laws about Flats. UU No. 20 Year 2011, LN No. 108 Year 2011.

Governmmental Law about Flats. GL No. 4 Year 1988.

Indonesian Ministry of People Housing. Ministry's Provision on People's Housing about

Flats Trading Association Guidance. Menpera’s Provision No. 11/KPTS/1994.

Indonesian Ministry of People Housing. Ministry's Provision on People's Housing about the

Guidance of Deed of Incorporation Creation on Articles of Association and Bylaws of Flats Owners. Menpera’s Provision No. 06/KPTS/BKP4N/1995. 